\title{
Total Parenteral Beslenen Hastalarda Yaşam Kalitesinin Değerlendirilmesi*
}

\author{
Assessment of Quality of Life of Patients Fed with Total Parenteral Nutrition
}

\author{
Seda CEVHEROĞLU**, Rengin ACAROĞLU***
}

İletişim/Correspondence: Seda CEVHEROĞLU Adres/Adress: Doğu Akdeniz Üniversitesi Sağlık Bilimleri Fakültesi Hemşirelik Bölümü, Gazimağusa / KKTC Tel: 039263039 09/1070 Fax: 03926303940 E-mail: seda.cevheroglu@emu.edu.tr

\section{$\ddot{O} Z$}

Amaç: Çallşma, Total parenteral beslenme (TPB) uygulanan hasta bireylerde yaşam kalitesini ve yaşam kalitesini etkileyen faktörleri değerlendirmek amacı ile yapıldı.

Yöntem: Tanımlayıcı ve ilişki arayıcı tipte planlanan bu çalışma, total parenteral beslenme uygulanan 80 hasta birey ile yürütüldü. Verilerin toplanmasında, yapılandırılmış soru formu ve SF-36 Sağllkla İlişkili Yaşam Kalitesi Ölçeği kullanıld. Verilerin analizi SPSS 15,0 paket programı ile bilgisayar ortamında tanımlayıcı istatistikler, parametrik testler ve korelasyon analizi kullanılarak yapıldl.

Bulgular: Hastaların sağllkla ilişkili yaşam kalitesi puan ortalamaları tüm alt boyutlarda düşük bulundu. "Sosyal Fonksiyon" alt boyutu ile yaş arasında zaylf düzeyde negatif yönde bir ilişki olduğu $(r=-0,279)$ ve bu yaşam alanının çocuk durumundan etkilendiği $(p=0,028)$ belirlendi. Komplikasyon varlığına $(p=0,046)$ ve hiperglisemi deneyimleme durumuna ( $p=0,041)$ göre "Fiziksel Fonksiyon" alt boyut puan ortalamasinin; ek hastallk durumuna göre 'Emosyonel Rol Kisitllilığ ' $(p=0,041)$ alt boyut puan ortalamasinin istatistiksel olarak anlaml farklllık gösterdiği saptandl.

Sonuç: TPB uygulanan hasta bireylerin yaşam kalitesinin kötü olduğu, yaş ve çocuk varliğl gibi sosyo-demografik özelliklerin, komplikasyon gelişimi ve özellikle hiperglisemi deneyimlemenin yanı sıra ek hastalık varlığının yaşam kalitesini olumsuz etkilediği belirlendi.

Anahtar Kelimeler: Total parenteral beslenme, sağlıkla ilişkili yaşam kalitesi, hemşirelik.

\begin{abstract}
Aim: This study is planned to assess the quality of life and the factors affecting quality of life in individuals fed with total parenteral nutrition (TPN).

Method: This descriptive and relationship detecting type of study was carried out with 80 tpn taking patient. Structured questionnaire and The Mos 36 Item Short From Health Survey-SF-36 was used for collecting the data. Data analysis was done with SPSS 15.0 package program by descriptive statistics, parametric tests and correlation analysis.

Results: Health-related quality of life mean scores were significantly lower in all the sub-dimensions. There was a weak level of negative correlation between 'The Social Function' sub-dimension and age $(r=-0.279)$, and these habitats was impacted by the status of the child $(p=0.028)$ were determined. 'Physical Function'sub-dimension mean scores showed statistically significant differences according to complications presence $(p=0.046)$, and hyperglycemia experiencing status $(p=0.041)$ and 'emotional role limitations' $(p=0.041)$ sub-dimension average score showed statistically significant differences according to additional disease states.

Conclusion: TPN fed patients have bad quality of life and factors as age, and having children, socio-demographic characteristics, having complication and particularly experience of hyperglycemia and presence of concomitant disease adversely affected quality of life.
\end{abstract}

Key Words: Total parenteral nutrition, health-related quality of life, nursing.

*İstanbul Üniversitesi Sağlık Bilimleri Fakültesi Yüksek Lisans Tezi 2014, **Öğr. Gör. Doğu Akdeniz Üniversitesi Sağlık Bilimleri Fakültesi Hemşirelik Bölümü, *** Prof. Dr. İ.Ü. Florence Nightingale Hemşirelik Fakültesi

Yazının gönderilme tarihi: 30.12.2014

Yazının basım için kabul tarihi: 28.05.2015 


\section{GíRiş}

Sağlıklı yaşam, yaşamın korunması ve sürdürülmesi organizmanın fizyolojik ve metabolik fonksiyonlarını yerine getirmesi ile mümkündür. Yeterli ve dengeli beslenme ise bu yaşamsal fonksiyonların düzenli bir şekilde sürdürülmesinde insanın en temel gereksinimlerinden biri olup sağlığın korumasında olduğu kadar hastalıkların önlenmesi ve tedavisinde dolayısı ile yaşam kalitesinin arttırılmasında önemli rol oynar (Çelebi 2010).

Yeterli ve dengeli beslenmenin sağlanmasında en uygun, en kolay ve en doğal yol besinlerin ağız yolu ile alınarak sindirim sürecinin başlamasıdır. Ancak bazı durumlarda bireyin ağız yolu ile beslenememesi ya da vücudun enerji gereksinimini karşılayamaması farklı beslenme yöntemlerini gündeme getirebilir. $\mathrm{Bu}$ yöntemlerden biri Total Parenteral Beslenme (TPB)'dir (Çelebi 2010).

TPB her ne kadar bireye yarar sağlamak amacı ile uygulansa da bazı komplikasyonları beraberinde getirir. Bunlar; katetere bağlı komplikasyonlar, metabolik komplikasyonlar ve enfeksiyon komplikasyonlar1dır. TPB uygulanan hasta bireylerde görülen bu komplikasyonlar, tedavinin başarısızlıkla sonuçlanmasına ve hasta bireylerin sağlikla ilişkili yaşam kalitesinin olumsuz etkilenmesine yol açabilecek kadar önemli boyutlara ulaşabilir (Başaran, Güzel ve Sarpe 2005; Özdemir 2006; Reis 2003).

Yaşam kalitesi; yaşam doyumu, yaşam memnuniyeti ve mutluluk kelimeleriyle eş anlamlı olarak kullanılan, bireyin biyo, psiko, sosyokültürel ve politiko-ekonomik boyutunu etkileyen geniş bir kavramdır. Sağlıkla ilişkili yaşam kalitesi ise yaşam kalitesinin sadece bir bölümünü oluşturmakta ve bireyin içinde bulunduğu sağlik durumundan memnuniyet durumu ve sağllk durumuna verdiği emosyonel yanıtı da içeren bir kavram olarak kabul edilmektedir (Akyüz 2004). Sağlıkla ilişkili yaşam kalitesinin belirlenmesinde; hasta bireyin sağlik durumu, kişisel ve sosyo-kültürel özelliklerinin yans1ması olan istek ve beklentileri, sağlık durumu nedeniyle bu istek ve beklentileri gerçekleştirme yeteneğindeki kısıtlamalar ve hasta bireyin bu kısıtlamalar karş1- sındaki yanıtı rol oynamaktadır (Balcı, Genç, Demirer ve Aydıntuğ 2005; Savc1 2007).

Sağlıkla ilişkili yaşam kalitesini inceleyen birçok çalışma yapılmış ve sağlıktan sapmaya neden olan durumların yaşam kalitesini olumsuz yönde etkilediği görülmüştür (Brazier 1992; Sagui, Fernandes ve Allard 2014; Y1lmaz 2012). Ancak, TPB uygulanan hasta bireylerde yaşam kalitesini değerlendiren çalışmalar oldukça sınırlıdır (Yılmaz 2012). Bu sınırlı çalışmalarda, TPB tedavisine bağlı olarak gelişen komplikasyonların ve kateter ile ilgili bakım eksikliği ya da yanlış uygulamaların yaşam kalitesini olumsuz etkilediği belirtilmiştir (Delegge 2011; Fitzgerald 2004) Bununla birlikte, TPB uygulanan hasta bireyler, kanser, cerrahi girişimler veya nörolojik hastalıklar gibi yaşam kalitesini olumsuz etkileyecek sağlık problemlerine sahiptir. Komplikasyonların yanı sıra medikal cihazlar ile ilgili problemler, beslenme ürününü temin etme, cihaz ve ürünlerin kullanımı ile ilgili bilgi eksiklikleri gibi durumlar, sağlıkla ilgili yaşam kalitesini azaltan diğer sebeplerdir (Delegge 2011).

Total parenteral beslenme bireyin GYA'nin gerçekleştirilmesinde yoğun sorunlar yaşanmasına neden olarak bağımsızlı̆̆ını kaybetmesine, beraberinde ekonomik üretkenliğini yitirmesi ile aile içi ve toplumsal rollerini yerine getirememesine neden olabilmektedir. Bu bağlamda hemşire, öncelikle total parenteral beslenen hastaların bağımsızlığını sürdürmesine ya da bağımlılık durumu ile başa çıkmasına olanak sağlayacak davranışlar kazanmasına yardım etmelidir (Delegge 2011; Gündoğdu 2010).

Ülkemizde, son yıllarda, yaşam kalitesine ilişkin çalışmalarda bir artış olmasına karşın TPB uygulanan hasta bireylerin yaşam kalitesini belirlemeye yönelik herhangi bir araştırmaya rastlanmamıştır (Yılmaz 2012). $\mathrm{Bu}$ nedenle, çalışma total parenteral beslenme uygulanan hasta bireylerde yaşam kalitesini ve yaşam kalitesini etkileyen faktörleri değerlendirmek amacıyla planlanmış ve elde edilen verilerin TPB uygulanan hasta bireylerin sağlıkla ilişkili yaşam kalitesini arttırmaya yönelik hemşirelik bakımının planlanmasına katk1 sağlayabileceği düşünülmüştür. 


\section{YÖNTEM}

\section{Araştırmanın Amacı ve Tipi}

$\mathrm{Bu}$ çalışma, total parenteral beslenme uygulanan hasta bireylerde yaşam kalitesini ve yaşam kalitesini etkileyen faktörleri değerlendirmek amacıyla tanımlayıcı ve ilişki arayıcı tipte planlandı.

\section{Araştırmanın Evreni ve Örneklemi}

Araştırmanın evrenini Nisan 2009- Nisan 2010 tarihleri arasinda bir üniversite hastanesinin Genel Cerrahi servisinde yatan ve total parenteral beslenme uygulanan hasta bireyler oluşturdu. Araştırmanın örneklemi ise, aşağıda belirtilen kriterleri taşıyan ve araştırmanın amacı açıklanarak bilgilendirildikten sonra araştırmaya katılım için izin alınan toplam 80 hasta bireyden oluştu.

Örneklem seçiminde; hasta bireye total parenteral beslenme uygulanıyor olması, 18 yaş ve üstü olması, iletişim kurmayı engelleyen herhangi bir sağlık sorununun olmaması, çalışmaya katılmaya istekli ve gönüllü olması kriterleri dikkate alınd1.

\section{Veri Toplama Araçları}

Veriler, araştırmacı tarafından yapılandırılmış soru formu ve SF-36 Sağlıkla İlişkili Yaşam Kalitesi Ölçeği (The Mos 36 Item Short From Health Survey- SF-36) olmak üzere 2 form kullanılarak toplandı.

Literatür bilgisi doğrultusunda hazırlanan soru for$\mathrm{mu}$; yaş, cinsiyet, eğitim durumu, medeni durum, çocuk varlığı, yaşam durumu ve sosyo- ekonomik durum gibi sosyo-demografik özellikler ile var olan hastalık durumu, TPB uygulama süresi, TPB hakkında bilgi alma durumu, TPB komplikasyonları ve uygulama zorluklarını belirleyici soruları içerdi.

SF-36 1988'de Ware tarafindan geliştirilerek 1990'da "standart" formu oluşturulan, klinik araştırmalarda, sağlık politikalarının değerlendirilmesinde ve genel popülasyon incelemelerinde kullanılan bir ölçektir. SF-36 sağlıkla ilişkili genel değerlendirme sorularının yanı sıra fiziksel fonksiyon, fiziksel rol kısitlaması, genel sağlık, canlılık, sosyal fonksiyon, emosyonel rol k1sitlaması, mental sağlık ve ağrı olmak üzere 8 alt boyutta toplanan 36 soru içermektedir. Ölçek dördüncü ve beşinci maddeler dışında Likert tiptedir (üçlü-altılı), dördüncü ve beşinci maddeler evet/hayır biçiminde yanıtlanmaktadır. Ölçeğin her bir alt boyutu için ayrı ayrı puanlar elde edilir. Alt boyutlardan alınabilecek en düşük puan 0, en yüksek puan 100'dür. 0 puan kötü sağlık durumunu, 100 puan ise iyi sağlık durumunu gösterir.

Sağlıkla ilişkili yaşam kalitesi ölçeği SF-36, 1999 y1lında Koçyiğit ve arkadaşları tarafından geçerlilik ve güvenirlik çalışması yapılarak Türk toplumuna uyarlanmıştır (Koçyiğit, Aydemir ve Ölmez 1999).

Ware ve Sherbourne (1992) orijinal SF-36 geliştirme çalışmasında Cronbach alfa katsayısı 0,62-0,94 arasında bulunmuştur. Bu çalışmada Cronbach alfa katsayısı $=0,83$ değerine sahipti ve bu değer güvenirliğin yüksek olduğunu göstermektedir.

\section{Verilerin Toplanması}

Veri toplamada kullanılan formlar, hasta bireyler ile yüz yüze görüşülerek araştırmacı tarafından dolduruldu. Formların doldurulması yaklaşık 10-15 dk sürdü.

\section{Verilerin İstatistiksel Analizi}

Araştırma sonucu elde edilen verilerin analizi SPSS (Statistical Package for Social Sciences) 15,0 paket programı ile bilgisayar ortamında yapıldı. Hasta bireylerin sosyo-demografik özellikleri, hastalık ile ilgili özellikleri ve yaşam kalitesi değişkenleri sayı ve ortalama olarak verildi. Yaşam kalitesinin sosyo-demografik ve hastalığa ilişkin özelliklere göre karşılaştırılması t testi ve ANOVA varyans analizi ile değerlendirilirken; yaş ve TPB uygulama süresi ile yaşam kalitesi değişkenleri arasındaki ilişkinin incelenmesinde Pearson Korelasyon analizi kullanıldı. Sonuçlar \%95'lik güven aralığında, anlamlılık $\mathrm{p}<0.05$ düzeyinde değerlendirildi.

\section{Araştırmanın Etik ve Yasal Yönleri}

Araştırmanın yürütülebilmesi için İ.Ü. İstanbul Tıp Fakültesi Klinik Araştırmalar Etik Kurulu'ndan onay ve İ.Ü. İstanbul Tıp Fakültesi Genel Cerrahi Anabilim Dalı'ndan izin alındı. Çalışmaya katılımda gönüllülük ilkesine özen gösterildi ve örneklem grubunu oluşturan hastalara çalışmanın amacı, kendilerinden ne beklenildiği ve yasal hakları açıklandıktan sonra yazılı izin alındı. Elde edilen bilgilerin gizli tutulacağı güvencesi verildi. 


\section{Araştırmanın Sınırlılıkları}

Ülkemizde TPB tedavisinin yaşam kalitesine etkisini inceleyen çalışmaya rastlanmaması, yurt dışında ise oldukça sınırlı sayıda çalışma yapılmış olması elde edilen bulguların tartışılmasını sınırlandırdı. Örneklem grubunun randomize yöntemle seçilmemesi ve sayısı nedeniyle araştırma sonuçları genellenemedi.

\section{BULGULAR}

Araştırma kapsamına alınan hasta bireylerin sosyodemografik özelliklerinin dağılımları incelendiğinde; yaş ortalamasının 49,91 $\pm 13,09$ yıl, \%51,25'inin kadın, \%32,5'inin lise mezunu, \%70'inin evli, \%82,5'inin çocuk sahibi olduğu, $\% 63,75$ 'inin eş/çocuk ile birlikte yaşadığ $1, \% 67,5$ 'inin herhangi bir işte çalışmadığı ve \%61,25'inin ise özbildirimlerine göre sosyo-ekonomik durumunun orta düzeyde olduğu saptand1.

Hastalık ve TPB tedavisine ilişkin özellikleri incelendiğinde, \%68,75'ine kanser tanısı nedeniyle TPB uygulandığ $1, \% 48,75$ 'inin TPB endikasyonu dışında ek hastalığının olduğu, \%55'ine TPB'nin santral venöz kateter ile uygulandığ,$\%$ 76,25'ine TPB hakkında bilgi verildiği, bilgi aldığını ifade eden 61 hasta bireyin $\% 60,66$ 'sının TPB hakkındaki bilgiyi hem hekim hem de hemşirelerden aldığ 1 görüldü.

TPB tedavisi ile ilişkili veriler değerlendirildiğinde; beslenme süresinin ortalama 27,96 $\pm 3,14$ gün olduğu, $\% 17,50$ 'sinde hipertermi, \%22,5'inde hiperglisemi, $\% 2,50$ 'sinde dispne, $\% 23,75$ 'inde bulant1, \%10'unda kateter tıkanıklığı gibi komplikasyonların geliştiği, TPB uygulaması ile birlikte \%83,75'inin oral yol ile ek gıda almadığı, \%68,75'inin uyku düzeninin etkilendiği, $\% 58,75$ 'inin kendisini günlük yaşam aktivitelerinde bağımlı hissettiğini ifade ettiği saptandı (Tablo 1).

TPB uygulanan hasta bireylerin SF-36 ölçeği alt boyutlarından aldığı puan ortalamalarının dağılımları incelendiğinde; genel olarak puan ortalamalarının düşük olduğu, en düşük puan ortalamasının "Fiziksel rol k1sitl1lığı" alt boyutunda $(0,63 \pm 3,9)$ olduğu, en yüksek puan ortalamasının ise " Genel Sağlık" alt boyutundan $(49,38 \pm 12,8)$ aldığ 1 saptandı (Tablo 2).
Tablo 1. TPB Tedavisine Karşı Yanıtların Dağılımı (N=80)

\begin{tabular}{|c|c|c|}
\hline & Sayı (n) & Yüzde (\%) \\
\hline $\begin{array}{l}\text { TPB Süresi } \\
\text { Ortalama }\end{array}$ & $27,96 \pm 3,14$ gün & $\begin{array}{l}\text { Min.: } 15 \text { gün } \\
\text { Max.:180 gün }\end{array}$ \\
\hline $\begin{array}{l}\text { TPB Komplikasyonları } \\
\text { Var } \\
\text { Yok }\end{array}$ & $\begin{array}{l}35 \\
45\end{array}$ & $\begin{array}{l}43,75 \\
56,25\end{array}$ \\
\hline $\begin{array}{l}\text { Hipertermi } \\
\text { Yok } \\
\text { Var }\end{array}$ & $\begin{array}{l}66 \\
14\end{array}$ & $\begin{array}{l}82,50 \\
17,50\end{array}$ \\
\hline $\begin{array}{l}\text { Hiperglisemi } \\
\text { Yok } \\
\text { Var }\end{array}$ & $\begin{array}{l}62 \\
18\end{array}$ & $\begin{array}{l}77,50 \\
22,50\end{array}$ \\
\hline $\begin{array}{l}\text { Dispne } \\
\text { Yok } \\
\text { Var }\end{array}$ & $\begin{array}{l}78 \\
2\end{array}$ & $\begin{array}{l}97,50 \\
2,50\end{array}$ \\
\hline $\begin{array}{l}\text { Bulantı } \\
\text { Yok } \\
\text { Var }\end{array}$ & $\begin{array}{l}61 \\
19\end{array}$ & $\begin{array}{l}76,25 \\
23,75\end{array}$ \\
\hline $\begin{array}{l}\text { Kateter Tıkanıklığı } \\
\text { Yok } \\
\text { Var }\end{array}$ & $\begin{array}{l}72 \\
8\end{array}$ & $\begin{array}{l}90,00 \\
10,00\end{array}$ \\
\hline $\begin{array}{l}\text { Oral Yolla Beslenme } \\
\text { Durumu } \\
\text { Ek gida aliyor } \\
\text { Ek gida almiyor }\end{array}$ & $\begin{array}{l}13 \\
67\end{array}$ & $\begin{array}{l}16,25 \\
83,75\end{array}$ \\
\hline $\begin{array}{l}\text { Uyku Düzeni } \\
\text { Etkilenmedi } \\
\text { Etkilendi } \\
\end{array}$ & $\begin{array}{l}25 \\
55\end{array}$ & $\begin{array}{l}31,25 \\
68,75\end{array}$ \\
\hline $\begin{array}{l}\text { Günlük Yaşam } \\
\text { Aktiviteleri } \\
\text { Bağımsız hissetme } \\
\text { Bağımlı hissetme }\end{array}$ & $\begin{array}{l}33 \\
47\end{array}$ & $\begin{array}{l}41,25 \\
58,75\end{array}$ \\
\hline
\end{tabular}

Tablo 2. Sağlıkla İlişkili Yaşam Kalitesi Ölçeği (SF-36) Puan Ortalamaları $(\mathrm{N}=80)$

\begin{tabular}{|l|c|c|c|}
\hline SF-36 Alt boyutlart & Ortalama \pm SS & Max. & Min. \\
\hline Fiziksel fonksiyon & $28,75 \pm 30,3$ & 95 & 0 \\
\hline Fiziksel rol kısıtl1lığ & $0,63 \pm 3,9$ & 25 & 0 \\
\hline Genel sağlık & $49,38 \pm 12,8$ & 90 & 15 \\
\hline Canlılık & $39,44 \pm 19,9$ & 90 & 10 \\
\hline Sosyal fonksiyon & $27,19 \pm 17,8$ & 100 & 0 \\
\hline $\begin{array}{l}\text { Emosyonel rol } \\
\text { kısıtlılığ1 }\end{array}$ & $7,49 \pm 19,1$ & 67 & 0 \\
\hline Mental sağlık & $47,50 \pm 17,1$ & 92 & 12 \\
\hline Ağr1 & $37,03 \pm 23,8$ & 100 & 0 \\
\hline
\end{tabular}




\begin{tabular}{|c|c|c|c|c|c|c|c|c|c|c|}
\hline & 焉 & 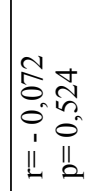 & 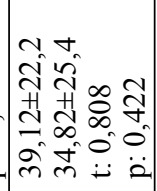 & 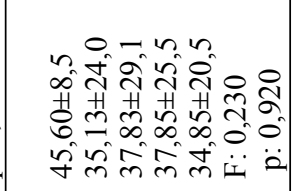 & 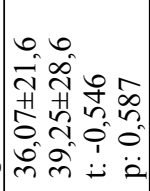 & 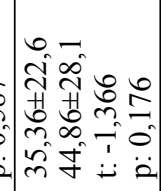 & 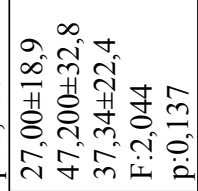 & 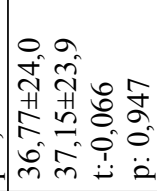 & 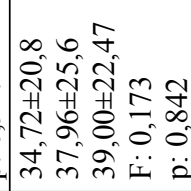 & 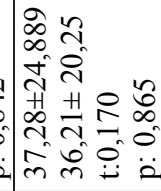 \\
\hline & 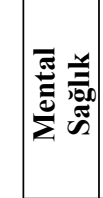 & $\begin{array}{ll}\hat{2} & 0 \\
1 & 0 \\
0 & 0 \\
1 & 0 \\
11 & 11 \\
1 & 0\end{array}$ & 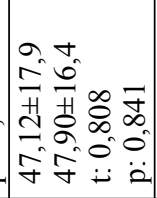 & 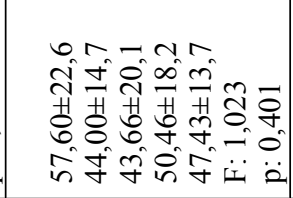 & 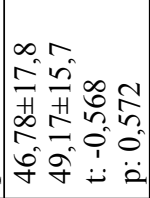 & 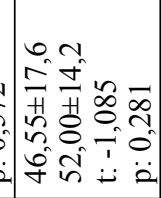 & 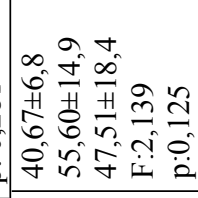 & 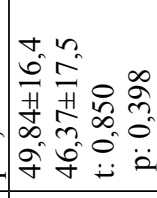 & 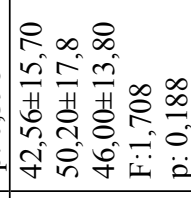 & 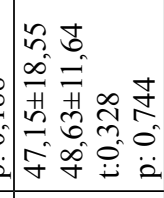 \\
\hline & 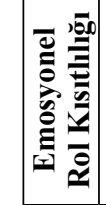 & \begin{tabular}{|cc} 
& \\
0 & \\
0 & 0 \\
0 & 0 \\
0 & 0 \\
1 & 0 \\
11 & 11 \\
11 & 2
\end{tabular} & 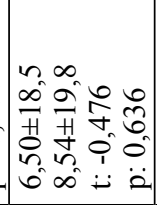 & 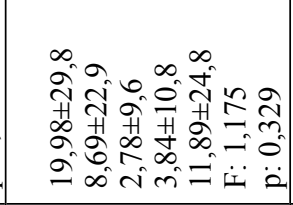 & 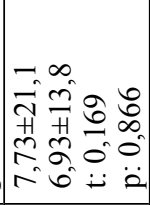 & 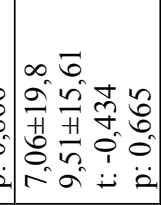 & 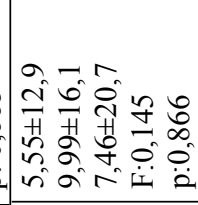 & 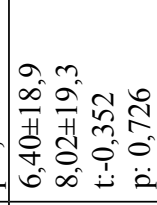 & 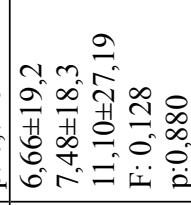 & 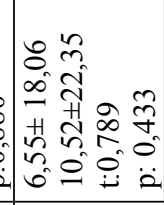 \\
\hline & 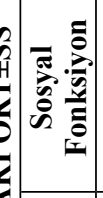 & 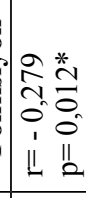 & 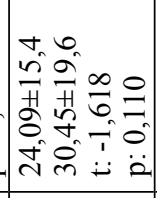 & 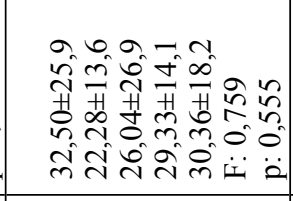 & 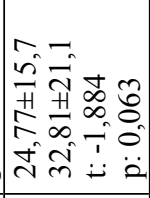 & 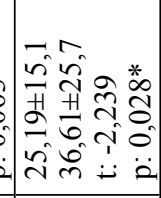 & 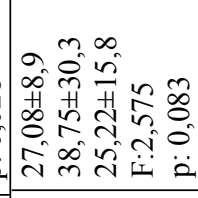 & 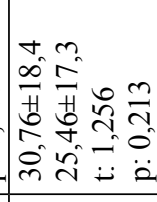 & 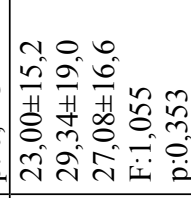 & 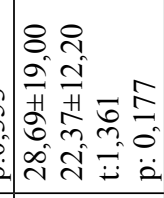 \\
\hline & Ũ & 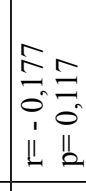 & 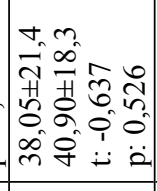 & 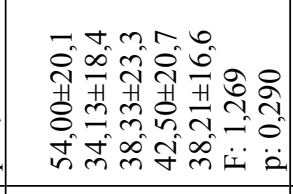 & 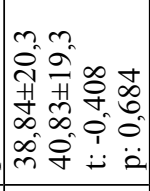 & 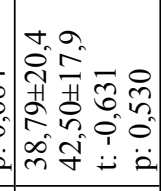 & 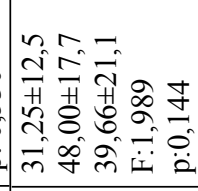 & 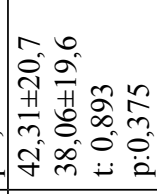 & 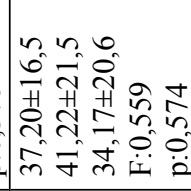 & 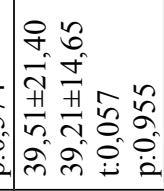 \\
\hline & 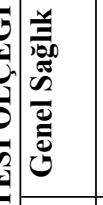 & 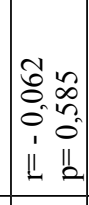 & 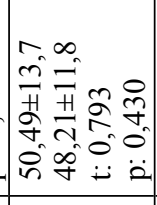 & 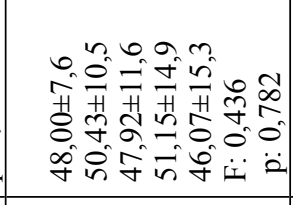 & 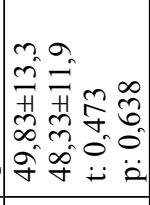 & 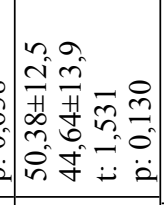 & 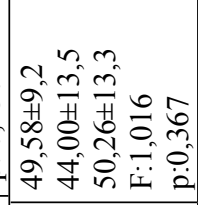 & 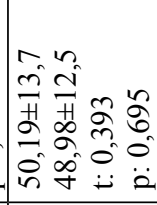 & 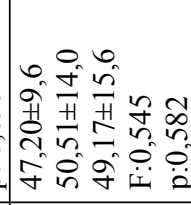 & 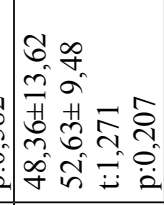 \\
\hline & 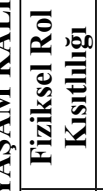 & 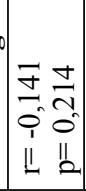 & 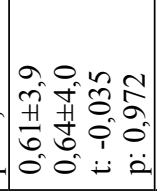 & 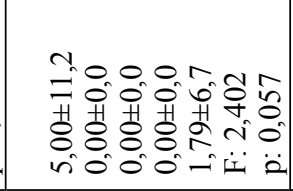 & 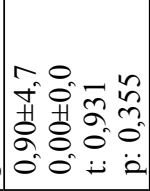 & 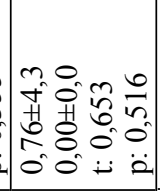 &  & 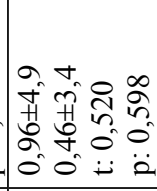 & 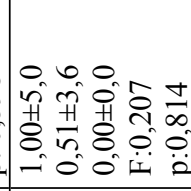 & 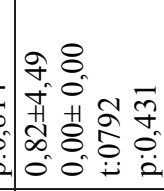 \\
\hline & 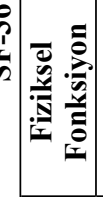 & 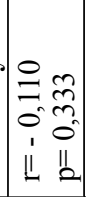 & 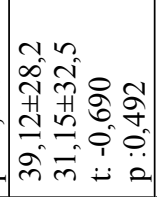 & 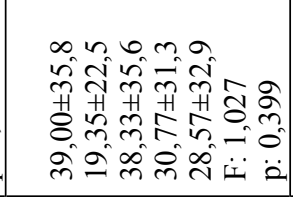 & 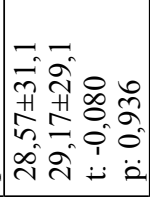 & 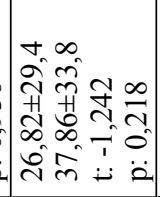 & 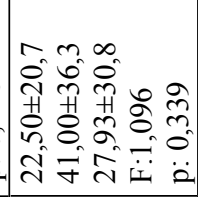 & 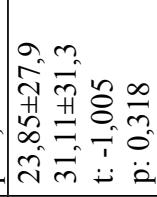 & 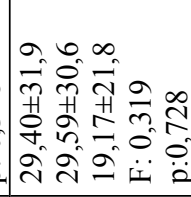 & 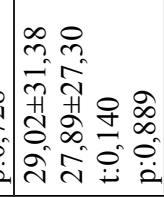 \\
\hline & & 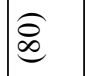 & 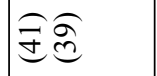 & 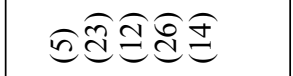 & 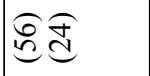 & हैं & 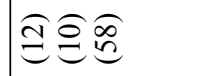 & 宅息 & 军全 & $\widehat{\bar{\sigma}} \widehat{\varrho}$ \\
\hline & 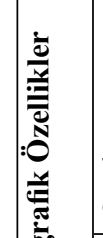 & 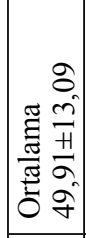 & 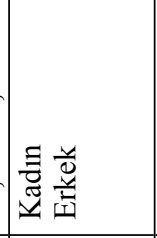 & 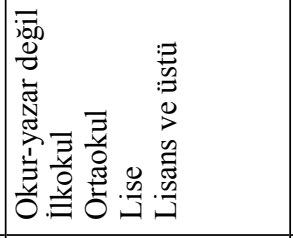 & 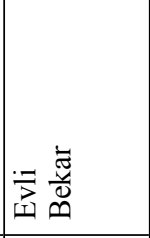 & iี & 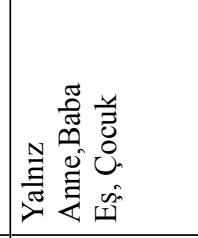 & 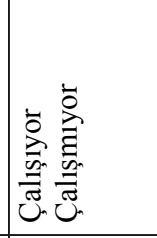 & 滈 & 紊茜 \\
\hline & 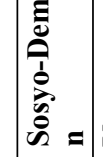 & $\underset{\pi}{\approx}$ & 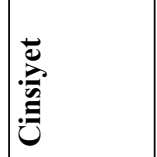 & 高音 & 焉 & 品 & 高 & 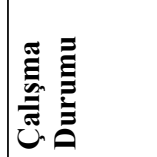 & 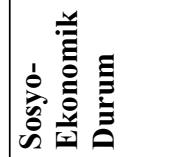 & 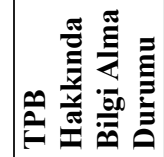 \\
\hline
\end{tabular}


Sosyo-demografik özellikleri ve sağlıkla ilişkili SF-36 yaşam kalitesi ölçeği alt boyut puan ortalamaları incelendiğinde; yaş ile sadece "Sosyal Fonksiyon" alt boyutu arasında negatif yönde ve zayıf düzeyde bir ilişki olduğu görüldü (r: 0,279; p<0,05). Hasta bireylerin yaşları arttıkça 'Sosyal Fonksiyon' alanına ilişkin sağlıkla ilişkili yaşam kalitelerinin azaldığı görüldü (Tablo 3).

Hasta bireylerin TPB tedavisine karşı yanıtlarına göre sağlıkla ilişkili yaşam kalitesi puan ortalamaları incelendiğinde; TPB süresi ile sağlıkla ilişkili yaşam kalitesi ölçeği alt boyutları arasında anlamlı bir ilişki saptanmadı ( $p>0,05)$. Komplikasyon gelişen hasta bireylerin "Fiziksel Fonksiyon" alt boyutundan aldıkları puan ortalamasının daha düşük olduğu görüldü. Bu farklılık istatistiksel açıdan da anlamlı bulundu $(\mathrm{t}=2,028 ; \mathrm{p}<0,05)$. Hiperglisemi deneyimleme durumuna göre yaşam kalitesi "Fiziksel Fonksiyon" alt boyut puan ortalamaları arasinda istatistiksel olarak anlamlı farklılık saptand $1(t=2,414 ; \mathrm{p}<0,05)$ ve hiperglisemi gelişen hasta bireylerin "Fiziksel Fonksiyon" alt boyutundan aldıkları puan ortalamasının daha düşük olduğu görüldü.

\section{TARTIŞMA}

Total parenteral beslenme uygulanan hasta bireylerde yaşam kalitesini ve yaşam kalitesini etkileyen faktörleri değerlendirmek amacıyla yapılan çalışmada, araştırma kapsamına alınan hasta bireylerin sağlıkla ilişkili yaşam kalitesi ölçeği alt boyutlarından aldığ puan ortalamaları incelendiğinde, genel olarak tüm alt boyut puan ortalamalarının düşük olduğu, en düşük puan ortalamasının "Fiziksel Rol Kısıtlılığı" alt boyutundan $(0,63 \pm 3,9)$, en yüksek puan ortalamasının ise 'Genel Sağlık' alt boyutundan $(49,38 \pm 12,8)$ alındığ 1 saptandı. Dolayısı ile hasta bireylerin sağlıkla ilişkili yaşam kalitesinin kötü düzeylerde ve en fazla etkilenen yaşam alanının 'Fiziksel Rol Kısıtlılığı' olduğu görüldü.

Dünyada ve ülkemizde kronik hastalıklarda yaşam kalitesinin incelendiği çeşitli araştırmalarda yaşam kalitesi puanları düşük bulunmuştur (Balles ve ark. 2006;
Soyyiğit, Erk, Güler ve Kılınç 2006; Şakar, Yorganc1oğlu, Aydemir, Sepit ve Çelik 2007). Yıldız, Yücel, Efe, Karabuğa ve Pınar (2007)'ın 'Kanserli hastalarda yaşam kalitesi' çalışmasında ortalama yaşam kalitesi puanının $63,95 \pm 2,24$ olduğu saptanmış ve yaşam kalitesinin kanserden olumsuz etkilendiği belirtilmiştir. Üner ve ark. (2007)'nın kanser hastalarının yaşam kalitelerinin SF-36 ölçeği ile değerlendirildiği çalışmada, yaşam kalitesi ölçeğinden en yüksek puanı 'Mental Sağl1k' alt boyutu, en düşük puanı ise 'Fiziksel Rol Kısıtlılı̆ğ' alt boyutu almış ve kanser hastalarının yaşam kalitelerinde azalma olduğu görülmüştür. Havlucu (2007a)'nun KOAH'lı olgularda yaşam kalitesi çalışması ile yine Havlucu (2007b)'nun Astım'lı hastaların yaşam kalitesini değerlendirdiği çalışmada da hasta bireylerin yaşam kalitelerinin azaldığ belirlenmiştir. Çalışmadan elde edilen bulgunun, bu çalışmalar ile benzerlik göstermesi, araştırma örneklemini oluşturan hasta bireylerin büyük çoğunluğunun kronik hastal1ğa sahip olmasının yaşam kalitelerindeki olumsuzluğu artırdığını düşündürdü.

TPB uygulanan hasta bireyler üzerinde yaşam kalitesini inceleyen çalışmalarda da 'Fiziksel Fonksiyon' alt boyutu en düşük puanı almıştır (Cameron, Benjamin, Mc Kay, Yang ve Perdue 2002; De Francesco ve ark. 1997; Jeppesen, Langhoiz ve Mortensen 1997; Malone 2002; Richards, Deeks, Sheldon ve Shaffer 1997; Winkler 2005). Saqui ve ark. (2014)'nın yaptığı araştırmada, sabit infüzyon makinaları yerine taşınabilir infüzyon makinaları kullanıldı̆̆ında, hasta bireylerin fiziksel rollerinin daha yüksek olduğu tespit edilmiştir. Winkler, Hagan, Wetle, Smith ve Maillet (2010) yaptığı çalışmada özellikle yaşlı hasta bireylerde 'Fiziksel Fonksiyon' alt boyutunun oldukça düşük olduğu görülmüştür. Winkler (2005)'in 'evde TPB uygulanan yetişkin bireylerin yaşam kalitesi' çalışmasında 'Fiziksel fonksiyon, Emosyonel Rol Kisitlılı̆g 1 ve Sosyal Fonksiyon' alanlarında yaşam kalitesinin azald1ğına ilişkin sonuçlar elde edilmiştir. Chambers, Hennessy ve Powell- Tuck (2006)'ın ' Evde TPB uygulanmaya başlanan hastaların kesitsel olarak incelenmesi' konulu çalışmasında, tedavinin ilk 6 aylık döneminde, 
yaşam kalitesi ölçeği alt boyutlarından 'Emosyonel Rol Kısıtlılığı ve Mental Sağlık' puanlarında anlamlı derecede azalma olduğu belirlenmiştir. Pironi ve ark. (2006)'nın 'Bağırsak nakli sonrası evde TPB beslenmeye başlayan hastaların yaşam kalitesi' konulu çalışmasında yaşam kalitesi ölçeği 'Ağrı' alt boyut puanlarında önemli faklılıklar tespit edilmiştir. Araştırma kapsamına alınan TPB uygulanan hasta bireylerin 'Fiziksel Rol Kısıtlılığı' yaşam alanında daha düşük puan almasının; hasta bireylerin 24 saat boyunca infüzyon pompalarına bağlı kalmaları, geçirmiş oldukları cerrahi girişimler, var olan ek hastalıkları, yoğun uygulanan tedavi ve bunların yol açtığı ruhsal durumlardan kaynaklandığı düşünüldü.

Araştırma kapsamına alınan hasta bireylerin yaş ortalaması ile sağlıkla ilişkili yaşam kalitesi ölçeği alt boyutları arasındaki ilişki incelendiğinde, yalnızca 'Sosyal Fonksiyon' alt boyutu ile zayıf düzeyde negatif yönde bir ilişki olduğu, hasta bireylerin yaşları arttıkça sosyal faaliyetlere ilişkin yaşam alanının daha da kötüleştiği görüldü $(r=-0,279 ; p=0,012 ; p<0,05)$. Saqui ve ark. (2014)'nın evde TPB uygulanan stomal1 hasta bireylere yönelik çalışmasında, yaşlı hastaların yetişkin hastalara göre yaşam kalitesi 'Genel Sağlık ve Sosyal Fonksiyon’ alt boyut puanlarının düşük olduğu saptanmıştır. Pınar (1994)'ın çalışmasında yaş ortalaması $48,57 \pm 18,10$ y1l olup, yaş ile yaşam kalitesi arasında negatif bir ilişki olduğu ve yaş arttıkça yaşam kalitesinin azaldığı belirtilmiştir. Literatürde, genç yaştaki hasta bireylerin yaşam kalitesinin yüksek bulunmasının nedeni olarak; gençlerin geleceklerine dair planlarının ve bunları gerçekleştirebilmek için hayattan beklentilerinin daha fazla olması, ileri yaştaki bireylere göre daha umutlu ve sorunlarla baş etmede daha mücadeleci olmaları gösterilmektedir. Subaş1 (2010)'nın çalışmasında da yaş'ın artması ile yaşam kalitesinin düşmesi bu bireylerin yaşamdan beklentilerinin daha az olmasının yanı sıra vücut direnci vb. yaşamsal fonksiyonlarının azalmasının yarattığı umutsuzluğa bağlanmıştır.

Araştırma kapsamına alınan hasta bireylerin çocuk sahibi olma durumuna göre sağlıkla ilişkili yaşam kali- tesi ölçeği 'Sosyal Fonksiyon' alt boyutu puan ortalamalarında anlamlı bir farklılık saptand $1(\mathrm{t}=-2,239$; $\mathrm{p}=0,028 ; \mathrm{p}<0,05)$. Çocuğu sahibi olan hasta bireylerin 'Sosyal Fonksiyon' alt boyutundan aldığ puan ortalamasının daha düşük olduğu görüldü. Subaş1 (2010)'nın 'Kanser ağrısı deneyimleyen hasta bireylerin yaşam kalitesi ve başetme tutumlarının değerlendirilmesi' çalışması ile Işıkhan ve ark. (2001)'nın 'Kanser hastalarının kaliteli yaşam ve hastalık özellikleri arasındaki ilişki' çalışmasında, eş ve çocuk sahibi olan hasta bireylerin yaşam kalitelerinin yüksek olduğu görülmüsstür. Bu hasta bireylerin 'Fiziksel Fonksiyon' ve 'Sosyal Fonksiyon' alt boyut puanları diğer gruplara göre daha yüksek bulunmuştur. Bu çalışmada hasta bireylerin 'Sosyal Fonksiyon' alt boyutundan en düşük puanı alması, örneklem grubunun hastanede yatan hasta bireylerden oluşmasının bir sonucu olarak düşünülebilir.

Araştırma kapsamına alınan hasta bireylerde komplikasyon varlı̆̆ına göre sağlıkla ilişkili yaşam kalitesi ölçeği alt boyutları puan ortalamaları incelendiğinde; istatistiksel olarak sadece "Fiziksel Fonksiyon" alt boyutuna ilişkin anlamlı farklılık saptandı $(\mathrm{t}=2,028$; $\mathrm{p}<0,05)$ ve komplikasyon gelişmeyen hasta bireylerde 'Fiziksel Rol Kısıtlılığı, Emosyonel Rol Kısıtlılığı ve Mental Sağlık' alt boyutları dışında diğer alt boyutlarına ilişkin puan ortalamaları daha yüksek bulundu. $\mathrm{Bu}$ bulgu, TPB tedavisine bağlı olarak gelişen komplikasyonların yaşam kalitesini olumsuz etkilediğini bildiren literatüre bilgisi ile uyum gösterdi (Allisoon, Fürst, Meier, Pertkiewicz ve Soeters 2004; Delegge 2011; Kahveci, Demirağ, Demirkan ve Uyar 2011).

Gelişen komplikasyonların yaşam kalitesine etkisi incelendiğinde; Hiperglisemi deneyimleme durumuna göre sağlıkla ilişkili yaşam kalitesi ölçeği alt boyutları puan ortalamaları arasında istatistiksel olarak sadece "Fiziksel Fonksiyon" alt boyutunda anlamlı farkl1lık saptandı $(t=2,414 ; p<0,05)$. Güven (2007)'in çalışmasında komplikasyon deneyimleme ile yaşam kalitesi karşılaştırıldığında 'Ağrı ve Emosyonel Rol Kısıtl1lığı' alt boyutlarında istatistiksel olarak anlamlı farkl1- 
lıkla etkilendiği saptanmış ve uzun hastalık süresinin komplikasyon riskini arttırdığı ve komplikasyonların hasta bireylerin günlük yaşam aktivitelerini kısıtlayarak yaşam kalitesini azalttığı sonucuna varılmıştır. Özdemir, Hocaoğlu, Koçak ve Ersöz (2011) çalışmasında da hiperglisemi'nin hasta bireylerin yaşam kalitesini olumsuz yönde etkilendiği gözlenmiştir. Kanser ve diabet hastalarında yapılan çalışmalarda, hipertermi, bulantı ve kusma komplikasyonlarının yaşam kalitesini önemli ölçüde azalttığına dair sonuçlar elde edilmesine karşın (Genç 2011; Miller ve Kearney 2000) bu çalışmada, yukarıda sözü edilen komplikasyonların, sağlıkla ilişkili yaşam kalitesi üzerine etkisini ortaya koyan bir bulgu elde edilmemiştir.

TPB endikasyonu dışında hastalık varlığının yaşam kalitesini etkileme durumu incelendiğinde, hasta bireylerin ek hastalık varlığına göre sağlıkla ilişkili yaşam kalitesi ölçeği alt boyut puan ortalamaları arasinda istatistiksel olarak sadece "Emosyonel Rol K1sitlılığı" alt boyutu arasinda anlamlı farklılık saptand1. Ek hastalığı olan hasta bireylerin " Emosyonel Rol Kısitlılığı” alt boyutundan aldıkları puan ortalamasının daha düşük olduğu görüldü $(t=2,082 ; \mathrm{p}<0,05)$. Ç1tıl, Günay, Elmalı ve Öztürk (2010)'ün yapmış olduğu diabetik hastalarda yaşam kalitesi araştırmasında, ek kronik hastalık varlığının, yaşam kalitesini olumsuz etkilediği saptanmıştır. Güven (2007)'in yaptığı Diabetli hastalarda yaşam kalitesi çalışmasında, ek hastalığı olanlarda yaşam kalitesi ölçeği alt boyutlarının hiçbirinde anlamlı farklılık tespit edilmemiştir. Brazier (1992) birden fazla bedensel hastalığa sahip olmanın yaşam kalitesinin özellikle "Fiziksel fonksiyon ve Sosyal Fonksiyon" boyutları üzerine olumsuz etki ettiğini belirlemiştir. Yapılan birçok çalışmada, Brazier'in sonuçları ile uyumlu olarak ek hastalıkların varlığında, yaşam kalitesinin olumsuz etkilendiğini ve bunun özellikle fonksiyonel boyutlarda farklılık gösterdiğini belirtmişlerdir (Çıtıl ve ark. 2010; Güven 2007).

\section{SONUÇ VE ÖNERİLER}

Sonuç olarak, total parenteral beslenme uygulanan hasta bireylerin yaşam kalitesinin kötü olduğu, yaş ve çocuk varlığı gibi sosyo-demogrofik özelliklerin 'Sosyal Fonksiyon'; komplikasyon gelişimi ve özellikle hiperglisemi deneyimleme durumunun 'Fiziksel Fonksiyon'; ek hastalık varlığının ise 'Emosyonel Rol Kısıtlllığı’ alanlarına ilişkin yaşam kalitesi düzeyini daha da kötüleştirdiği görüldü.

$\mathrm{Bu}$ sonuç doğrultusunda TPB uygulanan hasta bireylerin yaşam kalitesinin değerlendirilerek bakım planlarında dikkate alınması, hasta bireye/ailesine /bakımını üstlenecek bireylere yönelik eğitim programlarının düzenlenmesi ve gereksinim duyduklarında başvurabilecekleri rehber kitapçıkların verilmesi önerilir.

\section{KAYNAKLAR}

Akyüz, N. (2004). Ülseratif kolitli hastalarda ameliyat olanlarla olmayanların yaşam kalitelerinin değerlendirilmesi. Doktora Tezi, İstanbul Üniversitesi Sağlık Bilimleri Enstitüsü, İstanbul.

Allisoon, P. A., Fürst, P., Meier, R., Pertkiewicz, M., Soeters, P (2004). Total parenteral beslenme. Kofral1, G. (Ed.). Klinik Nütrisyon Temel Kavramlar. 3. basım, LOGOS Yayınevi, İstanbul, 800900 .

Balles, S. K. ve ark. (2006). Hydroxyurea and sickle cell anemia: Effect on quality of life. Health and Quality of Life Outcomes, 4: 59.

Başaran, S., Güzel, R., Sarpe, T. (2005). Yaşam kalitesi ve sağlık sonuçlarını değerlendirme ölçütleri. Romatizma, 20: 55- 63.

Balc1, D., Genç, N., Demirer, S., Aydıntuğ, S. (2005). Total nutrisyon tedavisinde farmakolojik etkileşmeler. Yoğun Bakım Dergisi, 5: 42- 49.

Brazier, J. E. (1992). Validating the SF 36 Health Survey Questionnaire: New outcome measure primary care. BMJ, 30: 160 -164.

Cameron, H., Benjamin, M. A., Mc Kay, D. M., Yang, P. C., Perdue, M. H. (2002). Pharmacologic options for intestinal rehabilitation in patients with short bowel syndrome publication, J. Clinical Endocrinal Metab, 87: 1743-1749.

Chambers, A., Hennessy, E., Powell-Tuck, J. (2006). Longitudinal Trends in quality of life after starting home parenteral nutrition: A randomised controlled study of telemedicine. Clinic Nutrition; 25: 505-514.

Çelebi, Z. M. (2010). Hemşirelerin total parenteral beslenmeye yönelik bilgilerinin saptanması. Yüksek Lisans Tezi, Afyon Kocatepe Üniversitesi Sağlık Bilimleri Enstitüsü, Afyon.

Çıtıl, R., Günay, O., Elmalı, F., Öztürk, Y. (2010). Diyabetik hastalarda tıbbi ve sosyal faktörlerin yaşam kalitesine etkisi. Erciyes Tıp Dergisi, (32)4: 253-264. 
De Francesco, A. ve ark. (1997). Home parenteral nutrition in Italy: Data from The Italian National Register. Clinical Nutrition, 14: 6-9.

Delegge, H. M. (2011). Total parenteral beslenme. Topgül, K., Malazgirt, Z. (Ed.). Nütrisyon ve Gastrointestinal Hastalıklar. Nobel Tıp Kitapevleri, İstanbul, 50-250.

Fithzgerald, K. A. (2004). The psychological and social impact of home parenteral nutrition. Doctorate Thesis of Philosophy, University of İllinois, Chicago.

Genç, A. (2011). Kemoterapi alan hastalarda bulant1- kusmanın önlenmesinde Akupressure'ın etkinliği. Yüksek Lisans Tezi, İstanbul Üniversitesi Sağlık Bilimleri Enstitüsü, İstanbul.

Gündoğdu, H. (2010). Evde nütrisyon desteği. İç Hastalıkları Dergisi, 17: 257-267.

Güven, T. (2007). Diabetes mellituslu hastalarda yaşam kalitesi ve depresyon etkisinin araştırılması. Uzmanlık Tezi, Şişli Etfal Eğitim ve Araştırma Hastanesi, İstanbul.

Havlucu, Y. (2007a). KOAH'lı olgularda yaşam kalitesi, performans durumu, anksiyete ve depresyon arasındaki ilişkinin değerlendirilmesi. 2. Sağllkta Yaşam Kalitesi Kongresi, 05-07 Nisan, İzmir.

Havlucu, Y. (2007b). Astımlı olgularda yaşam kalitesi ile astım kontrol testi ve astım şiddet skalası arasındaki ilişkinin değerlendirilmesi. 2. Sağlıkta Yaşam Kalitesi Kongresi, 05-07 Nisan, İzmir.

Işıkhan, V. ve ark. (2001). The relationship between disease feature and quality life in patient with cancer-I. Cancer Nursing, 24(6): 490-495.

Jeppesen, P. B., Langhoiz, E., Mortensen, P. B. (1997). Quality of life in patients receiving home parenteral nutrition. BMJ Open Gastroenterology, 44: 844-852.

Kahveci, F., Demirağ, K., Demirkan, K., Uyar, M. (2011). ESPEN Life, Long, Learning Programme- 9, modül-parenteral nütrisyon desteği. Life, Long, Learning KEPAN Temel Eğitim Kursu, 30 Mart, Antalya.

Koçyiğit, H., Aydemir, Ö., Ölmez, N. (1999). SF-36'nın Türkçe için geçerliliği ve güvenirliliği. İlaç ve Tedavi Dergisi, 12: 102-106.

Malone, M. (2002). Longitudinal assesment of outcome, health status, and changes in lifestyle associated with long-termhome parenteral and enteral nutrition. JPEN; 26(1): 164-168.

Miller, M., Kearney, N. (2000). Chemotherapy-related nausea and vomiting-past reflections, present practice and future management. European Journal of Cancer Care,13(1): 71-81.

Özdemir, E. (2006). Enteral ve parenteral beslenmenin önemi. Güncel Gastroenteroloji Dergisi, 10(1): 98-101.

Özdemir, İ., Hocaoğlu, Ç., Koçak, M., Ersöz, Ö. H. (2011). Tip II Diyabetes Mellitus'lu hastaların yaşam kalitesi ve ruhsal belirtiler. Psikiyatri ve Nörolojik Bilimler Dergisi, 24: 128-138.
Pınar, R. (1994). Diabetüs Mellitus'lu hastaların yaşam kalitesi ve yaşam kalitesini etkileyen faktörlerin incelenmesi. Doktora Tezi, İstanbul Üniversitesi Sağlık Bilimleri Enstitüsü, İstanbul.

Pironi, L. ve ark. (2006). Quality of life on home parenteral nutrition or after intestinal transplantation. Ellsevier, 38(6): 1673-1675.

Reis, N. (2003). Jinekolojik kanserlerde yaşam kalitesi ve etkileyen faktörler. Doktora Tezi, İstanbul Üniversitesi Sağlık Bilimleri Enstitüsü, İstanbul.

Richards, D. M., Deeks, J. J., Sheldon, T. A., Shaffer, J. L. (1997). Home parenteral nutrition: A systematic review. Health Technol Assess, 1(1): 1-59.

Savcı, C. (2007). Parkinson hastalarında sağlıkla ilişkili yaşam kalitesinin değerlendirilmesi. Yüksek Lisans Tezi, İstanbul Üniversitesi Sağlık Bilimleri Enstitüsü, İstanbul.

Saqui, O., Fernandes, G., Allard, J. P. (2014). Quality of life analiysis during transition from stationary to portable infusion pump in home parenteral nutrition patients: A Canadian experience. NCP A.S.P.E.N., 29(1): 131-141.

Soyyiğit, Ş., Erk, M., Güler, N., Kılınç, G. (2006). Kronik obstrüktif akciğer hastalığında yaşam kalitesinin belirlenmesinde SF-36 sağlık taramasının değeri. Tüberküloz ve Toraks Dergisi, 54(3): 259-266.

Subaşı, D. (2010). Kanser ağrısı deneyimleyen hastaların yaşam kalitesi ve başetme tutumlarının değerlendirilmesi. Yükseklisans Tezi, Mersin Üniversitesi Sağl1k Bilimleri Enstitüsü, Mersin.

Şakar, A., Yorgancıoğlu, A., Aydemir, Ö., Sepit, L., Çelik, P. (2007). Effect of severity of asthma on quality of life. Tüberküloz ve Toraks Dergisi, 55(2): 135-140.

Üner, S. ve ark. (2007). Kanser hastalarının yaşam kalitelerinin SF-36 ölçeği ile değerlendirilmesi. 2. Sağlıkta Yaşam Kalitesi Kongresi, 05-07 Nisan, İzmir.

Yıldız, H., Yücel, P., Efe, F., Karabuğa, H., Pınar, R. (2007). Kanserli hastalarda yaşam kalitesi. 2. Sağlıkta Yaşam Kalitesi Kongresi, 05-07 Nisan, İzmir.

Yılmaz, E. (2012). Cerrahi hemşireliği ve yaşam kalitesi ile ilgili yapılan çalışmalar- Ulusal boyut. Cerrahi Bakım ve Yaşam Kalitesi Sетроzуити, 04 Mayıs 2012, Manisa.

Ware, J. E., Sherbourne, C. D. (1992). The Most 36- İtem Short Form Health Survey (SF-36). Mad. Care, 30(6): 473.

Winkler, M. F. (2005). Quality of life in adult home parenteral nutrition patients. JPEN, 29: 162.

Winkler, M. F., Hagan, E., Wetle, T., Smith, C., Maillet, J. (2010). An exploration of quality of life and the experience of living with home parenteral nutrition. JPEN, 34: 395. 